\title{
Front Matter: Volume 11662
}

, "Front Matter: Volume 11662," Proc. SPIE 11662, Frontiers in Biological Detection: From Nanosensors to Systems XIII, 1166201 (19 April 2021); doi: 10.1117/12.2596771

SPIE. Event: SPIE BiOS, 2021, Online Only 


\title{
PROGRESS IN BIOMEDICAL OPTICS AND IMAGING
}

\section{Frontiers in Biological Detection: From Nanosensors to Systems XIII}

\author{
Amos Danielli \\ Benjamin L. Miller \\ Sharon M. Weiss \\ Editors
}

6-11 March 2021

Online Only, United States

Sponsored and Published by

SPIE 
The papers in this volume were part of the technical conference cited on the cover and title page. Papers were selected and subject to review by the editors and conference program committee. Some conference presentations may not be available for publication. Additional papers and presentation recordings may be available online in the SPIE Digital Library at SPIEDigitalLibrary.org.

The papers reflect the work and thoughts of the authors and are published herein as submitted. The publisher is not responsible for the validity of the information or for any outcomes resulting from reliance thereon.

Please use the following format to cite material from these proceedings:

Author(s), "Title of Paper," in Frontiers in Biological Detection: From Nanosensors to Systems XIII, edited by Amos Danielli, Benjamin L. Miller, Sharon M. Weiss, Proceedings of SPIE Vol. 11662 (SPIE, Bellingham, WA, 2021) Seven-digit Article CID Number.

ISSN: 1605-7422

ISSN: 2410-9045 (electronic)

ISBN: 9781510641594

ISBN: 9781510641600 (electronic)

Published by

SPIE

P.O. Box 10, Bellingham, Washington 98227-0010 USA

Telephone +1 3606763290 (Pacific Time) · Fax +1 3606471445

SPIE.org

Copyright (c) 2021, Society of Photo-Optical Instrumentation Engineers.

Copying of material in this book for internal or personal use, or for the internal or personal use of specific clients, beyond the fair use provisions granted by the U.S. Copyright Law is authorized by SPIE subject to payment of copying fees. The Transactional Reporting Service base fee for this volume is $\$ 21.00$ per article (or portion thereof), which should be paid directly to the Copyright Clearance Center (CCC), 222 Rosewood Drive, Danvers, MA 01923. Payment may also be made electronically through CCC Online at copyright.com. Other copying for republication, resale, advertising or promotion, or any form of systematic or multiple reproduction of any material in this book is prohibited except with permission in writing from the publisher. The CCC fee code is $1605-$ $7422 / 21 / \$ 21.00$.

Printed in the United States of America by Curran Associates, Inc., under license from SPIE.

Publication of record for individual papers is online in the SPIE Digital Library.

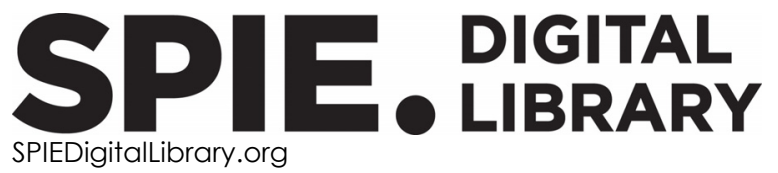

Paper Numbering: Proceedings of SPIE follow an e-First publication model. A unique citation identifier (CID) number is assigned to each article at the time of publication. Utilization of CIDs allows articles to be fully citable as soon as they are published online, and connects the same identifier to all online and print versions of the publication. SPIE uses a seven-digit CID article numbering system structured as follows:

- The first five digits correspond to the SPIE volume number.

- The last two digits indicate publication order within the volume using a Base 36 numbering system employing both numerals and letters. These two-number sets start with $00,01,02,03,04$, 05, 06, 07, 08, 09, 0A, OB ... 0Z, followed by 10-1Z, 20-2Z, etc. The CID Number appears on each page of the manuscript. 


\section{Contents}

PLASMONICS, RUORESCENCE, AND METASURFACES

1166203 Optical hom effect via hour-glass type nanostructure for biomolecule analysis [11662-13]

NEW DIAG NOSTICS FOR COVID-19 AND OTHER PANDEMIC VIRUSES

1166207 Viral nucleic acid detection with CRISPR-Cas12a using high contrast cleavage detection on micro-ring resonator biosensors (Invited Paper) [11662-8]

MICROLASERS

11662 OD Hydrogel microlasers forversatile biomolecular analysis based on lasing microanay [11662-3]

NEW APPUCATIONS IN OPTICALSENSING

11662 OE Mic rofluidic reaction design for real time chemical reactions monitoring [11662-4]

11662 OF Photonics-enabled lateral flow assay diagnostics [11662-5]

SENSTIVE DEIECTION APPROACHES

11662 0] Reduc ing detection limits of porous silic on thin film optical sensors using signal processing [11662-17]

POSTER SESSION

11662 OL Plasmonic nanovoids for monitoring sanitany conditions of a public place by surface-enhanced Raman spectrosc opy [11662-19] 
Proc. of SPIE Vol. 11662 1166201-4

\section{Downloaded From: https://www.spiedigitallibrary.org/conference-proceedings-of-spie on 26 Apr 2023
Terms of Use: https://www.spiedigitallibrary.org/terms-of-use}

